84

The Open Biotechnology Journal

RESEARCH ARTICLE

\title{
Recombinant Production and Molecular Docking Studies of Casoplatelin, a Bioactive Peptide
}

\author{
Ragothaman M. Yennamalli ${ }^{1,2}$, Pulkit Anupam Srivastava ${ }^{3}$, Sheena D. Sarswati ${ }^{3}$ and Vijay Kumar Garlapati, \\ ${ }^{1}$ Department of Microbial Technology, School of Biological Sciences, Madurai Kamaraj University, Madurai-625021, India \\ ${ }^{2}$ Department of Bioinformatics, School of Chemical and Biotechnology,SASTRA University, Thanjavur-613401, Tamil Nadu, India \\ ${ }^{3}$ Department of Biotechnology and Bioinformatics, Jaypee University of Information Technology, Waknaghat -173234, Himachal Pradesh, India
}

\begin{abstract}
:
Background:

Bioactive peptides from $\kappa$-casein have immense therapeutic potential as prophylactic formulations. Among these, casoplatelin is a $\kappa$-casein derived bioactive peptide with anti-thrombotic activities.

Aim:

Herein, we report the production of casoplatelin in an E. coli expression system (using a pBAD vector) and show in silico modeling of its interactions.

Methods:

A synthetic DNA construct encoding casoplatelin was designed with pepsin cleavage sites before and after the synthetic construct to allow the release of the peptide from the pro-peptide.

Results:

A novel recombinant approach was demonstrated for the production of casoplatelin, and anti-platelet aggregation activities of the product were confirmed. Also, casoplatelin structures were characterized in silico and then implemented to determine potential structural interactions with fibrinogen.

Conclusion:

The present study showcases the recombinant approach for biopeptide production and its interaction with fibrinogen through in silico approach.
\end{abstract}

Keywords: Casoplatelin, Bioactive peptide, Cloning, Molecular docking, Anti-thrombotic activity, Fibrinogen.

\section{INTRODUCTION}

Bioactive Peptides (BAP) constitute milk protein fragments with various reported therapeutic activities, including gastrointestinal, immunological, and nutritional effects [1]. Food matrixes contain various biofactors that can be produced using in vivo or enzymatic digestion approaches. Among these, BAPs are derived from animal and plant caseins,

\footnotetext{
* Address correspondence to this author at the Department of Biotechnology and Bioinformatics, Jaypee University of Information Technology, Waknaghat -173234, Himachal Pradesh, India; Tel: +91 1792 239288;

Fax: +91 1792 245362; E-mail: shanepati@gmail.com
}

and are nutraceutical candidates with utility as prophylactic formulations [2]. Such formulations have generally been recognized with safe (GRAS) status and substantial market demand. Hence, several researchers are actively investigating techniques for the production of BAP from food sources to meet the expected market demands [3]. Among plant and animal sources, milk proteins are the mainstay for the production of BAP using in vitro enzymatic digestion, and using in vivo and chemical approaches [4].

Overlapping peptide sequences of milk-derived peptides exerts various biological responses, such as ACE inhibition by $\beta$-casomorphins and $\beta$-lactorphin, immunostimulating effects 
of casokinins, and opioid activities of $\alpha$-lactorphin [5]. Casein glycomacropeptides (GMP) are found in sweet whey, and can be derived from the $\kappa$-casein using chymosin or trypsin. The carbohydrate portions $\mathrm{N}$-acetylneuraminic acid (NANA) and $\mathrm{N}$-acetylgalactosamine, and the peptide portions of $\kappa$-casein, are responsible for the biological effects of GMP. Although, mechanisms of carbohydrate-based biological responses are unknown, specific GMP peptides have distinct mechanisms for their respective biological functions [6].

Casoplatelin is an 11-amino acid peptide from GMP with the sequence MAIPPKKNQDK. The molecular bases of clotting in blood and milk have major similarities due to homology between cow $\kappa$-casein, which is a substrate of chymosin in milk clotting process, and the $\gamma$ chain of human fibrinogen, which plays a major role in blood clotting process [7]. Anti-thrombic mechanisms of $\kappa$-casein undecapeptide and human fibrinogen $\gamma$-chain (residues 400-411) were similar in a previous study, and were mediated by ADP-induced platelet aggregation and inhibition of fibrinogen binding [6]. Thus, anti-thrombotic mechanisms and production strategies for this undecapeptide were investigated [8].

Based on previous research reports, BAP production can be achieved by enzymatic cleavage of the precursor protein, by synthesizing the protein [9], or by expressing cloned cDNA or DNA encoding the protein precursor in mammalian systems, and subsequently introducing into non-human mammalian germline cells for gene expression in mammary glands. Alternatively, the cDNA sequence of human $\kappa$-casein was cloned into a prokaryotic expression vector to obtain the $\mathrm{BAP}^{8}$, and some studies report genetic engineering coupled with enzymatic/chemical cleavage strategies for the production of $\beta$ casomorphins [10]. However, all of these reported production technologies failed to give higher yields and required more production time. Hence, BAP production using these technologies is not sufficient to meet market expectations. Recent advances in computational biology and bioinformatics have allowed the development of computational models for studying peptide-protein interactions. Additionally, chemoin-formatics and chemometric methods are used frequently to study bioactive peptides $[11,12]$. The development of compu-tational model requires $3 \mathrm{D}$ structures of the peptide and its interaction partners. Homology modeling and ab-initio methods such as Robetta can be used to expedite charac-terizations of 3D protein structures in the absence of crystal structure data. Moreover, studies of interactions between biomolecules are often performed using molecular docking methods with opensource software such as DOCK and AutoDock, and with the commercially available software GOLD, FlexX, and Glide [13]. To investigate recombinant methods for the production of BAPs, we utilized a recombinant approach for the production of Casoplatelin in a prokaryotic expression system and proposed a molecular docking method using AutoDock to identify probable mechanisms of anti-thrombotic activity.

\section{MATERIALS AND METHODS}

\subsection{Chemicals, Materials and Reagents}

Two single-strand oligonucleotides were procured from
Microsynth, Switzerland. The Sequences are 5'ATGGCGATT CCGCCGAAAAAAAACCAGGATAAA3' and 5'TTTATC CTGGTTTTTTTTCGGCGGAATCGCCAT3'. T4 DNA ligase was obtained from New England Biolabs, USA. The pBADgIII version $\mathrm{C}$ and E.coli TOP 10 were procured from Invitrogen, USA. Kits for plasmid and BAP purification and labeling were purchased from Qiagen (USA) and Ambion Inc. (USA), respectively. Ampicillin, Streptomycin and Arabinose were procured from Sigma, USA.

\subsection{Synthesis and Annealing of Oligonucleotides}

Two single-strand oligonucleotides were suspended in MilliPore water (Model:Elix 3 UV Water Purification System $(120 \mathrm{~V} / 60 \mathrm{~Hz})$, Millipore, USA) at a final concentration of $100 \mu \mathrm{M}$. Oligonucleotide suspensions were then stored at $95^{\circ} \mathrm{C}$ for $5 \mathrm{~min}$ and were allowed to cool down gradually for proper annealing. Annealed products were then separated using a nondenaturing polyacrylamide gel.

\subsection{Cloning and Characterization of Cloned Oligonuc- leotide}

Cloning and characterization of casoplatelin were performed by annealing the oligonucleotide into a pBADgIII vector after digestion with Hind III and Pvu II, followed by purification using a Qiagen QIA Quick purification column. The linearized vector and synthetic construct were ligated using T4 DNA ligase (New England Biolabs, USA). After inactivation of T4 DNA ligase at $65^{\circ} \mathrm{C}$ for 10 min, mung bean nuclease digestion was performed to remove nucleotide overhangs. The partially ligated vector was further purified using a Qiagen QIA Quick purification column, and ligation was then performed at the $P v u I I$ site. Completely ligated vectors were then transformed into E.coli TOP 10 strain and cells were then plated on LB medium containing ampicillin (25 $\mu \mathrm{g} / \mathrm{ml})$. Colonies were then patched onto LB medium containing ampicillin $(25 \mu \mathrm{g} / \mathrm{ml})$ and streptomycin $(20 \mu \mathrm{g} / \mathrm{ml})$. After growth, plasmids were purified and characterized using a Dot-Blot Southern hybridization method with acrylamide gels from Denaturing Gradient Gel Electrophoresis (DGGE). After electrophoresis, gels were cut to fit the gel transfer stack and were subjected to a 5-min transfer step using the transfer membrane (Invitrogen, USA). Transfer membrane was then removed from the stack and was UV cross-linked for $10 \mathrm{~min}$ before hybridization [14]. Labeling was performed with BrightStar TM Psoralen-Biotin kits (Ambion Inc.) as described by the manufacturer.

\subsection{Overexpression and Purification of Casoplatelin}

Transformed clones were verified using Dot-Blot Southern hybridization and were then grown in the presence of arabinose $(0.1 \%)$ to induce overexpression of the peptide (Invitrogen pBAD instruction manual https://tools.thermofisher.com /content/sfs/manuals/pbadgiii_man.pdf). The overexpressed peptide was then purified using Qiagen Ni-NTA purification kits (Qiagen, USA). The molecular mass of the purified propeptide was estimated using SDS-polyacrylamide gel electrophoresis in $20 \%$ Tris-tricine [15]. 


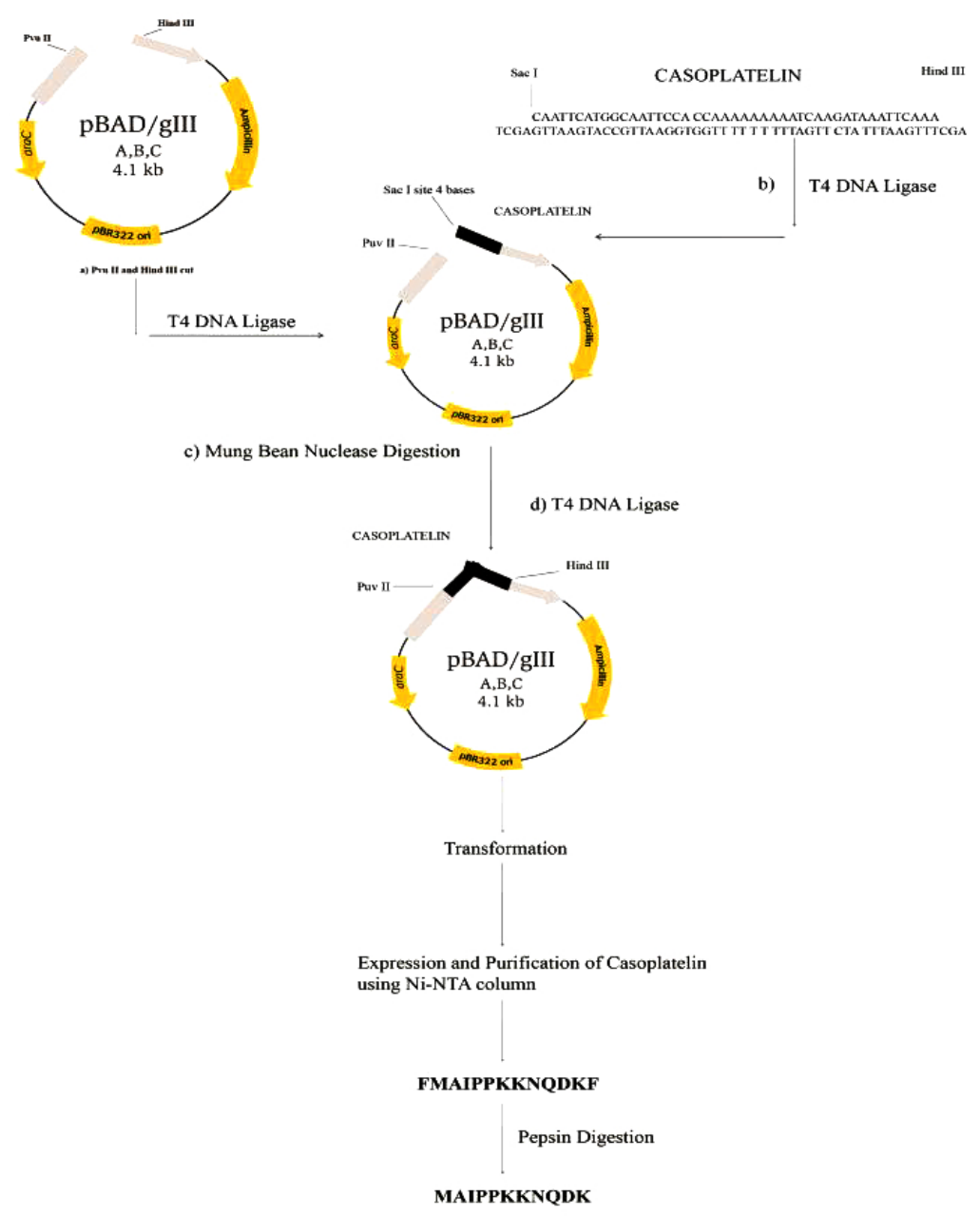

Fig. (1). $>$ Step-wise description of the proposed research approach. The schematic workflow used in this study is described here, where the oligonucleotide encoding the bioactive peptide, Casoplatelin, is inserted in the expression vector, followed by the transformation in $E$. coli cells. This is followed by expression and purification of the expressed bioactive peptide, post enzymatic digestion.

Table 1. The reaction mix was set as follows to check the antithrombotic activity.

\begin{tabular}{|c|c|c|}
\hline Component & Test Volume $(\boldsymbol{\mu L})$ & Control Volume $(\boldsymbol{\mu L})$ \\
\hline Platelet Suspension & 50 & 50 \\
\hline Pepsin Digested Fragments & 50 & n.d. \\
\hline Elution Buffer $\mathbf{E}$ & n.d. & 50 \\
\hline $\begin{array}{c}\text { Fibrinogen } \\
(\boldsymbol{\gamma}=\mathbf{0 . 7 5} \mathbf{~} \mathbf{g} \mathbf{m L})\end{array}$ & 10 & 10 \\
\hline $\begin{array}{c}\text { ADP (inducerc }=\mathbf{5} \boldsymbol{\mu M}) \\
\mathbf{5 M} \text { Final Concentration }\end{array}$ & 1 & 111 \\
\hline Total & 111 & 111 \\
\hline
\end{tabular}

n.d. = not determined

\subsection{Platelet Aggregation Assays}

The pro-peptide was prepared for assay by digesting it with pepsin in a gastric buffer. The anti-thrombotic activity was then verified through spectrophotometric analysis using a spectrophotometer (Model: UV1800, Shimadzu, Japan). Briefly, platelets for the assay were collected from $10-\mathrm{ml}$ human blood samples in anticoagulant buffer containing 318 $\mathrm{mM}$ citric acid, $62 \mathrm{mM}$ trisodium citrate, and $133 \mathrm{mM}$ glucose, which were prepared in the lab. Platelets were then suspended in $200 \mu \mathrm{l}$ of Tyrode's buffer, prepared in the lab. Details of the reaction mixture are presented in Table $\mathbf{1}$.

Control reaction mixtures were prepared identically except that pepsin-digested fragments were omitted. Absorbance values were recorded at $500 \mathrm{~nm}$ and were plotted as a function of time. The overall methodological approach utilized for recombinant casoplatelin is depicted in Fig. (1). 


\subsection{Prediction of 3D Structure and Computational Model of Casoplatelin and its Interaction with Fibrinogen}

The 3D structure of the peptide was generated to develop a computational model of casoplatelin and its interactions with fibrinogen using the ab-initio method (http://robetta. bakerlab.org) Robetta [16]. Robetta performs structure predictions by parsing the submitted sequence into putative domains and generates five structure models using comparative modeling or de novo structure predictions. These methods utilize hierarchies from BLAST, PSI-BLAST, FFAS03, or 3DJury to find protein homologs of known structure. When no positive matches are found, the sequence is used as a template for comparative modeling, and after further failure to find a positive match, de novo Rosetta fragment insertion is used to predict the structure.

Modeled structures were docked with fibrinogen using AutoDock 4.2 [17], which includes a two-step process in which the receptor is defined using a three-dimensional grid and then the peptide is docked using a Lamarckian genetic algorithm for pre-calculated grids. Agridbox of $126 \times 126 \times 126$ was created with a spacing of $1 \AA$ and a grid center of $-95.332,13.397$, and -15.749 was used to calculate grids. Element maps that were generated by AutoGrid for calculations included $\mathrm{Ca}^{2+}$ with other atom-specific affinity maps (C, HD, N, O, and S). AutoGrid also generates electrostatic and desolvation potential maps. Five peptide models from Robetta were docked onto fibrinogen using the Lamarckian Genetic Algorithm. In these computations, 10 runs were performed with a population size of 150 , a maximum number of energy evaluations of 2500000 , a maximum number of generations of 27000 , a mutation rate of 0.02 , and a crossover rate of 0.8 . The top 10 clustered docking results were ranked according to the lower binding energy. The peptide conformation that was ranked first among the ten was considered in further analyses using PyMOL and LIGPLOT [18].

\section{RESULTS AND DISCUSSION}

The most common methods for obtaining BAP involve enzymatic processing and/or in vivo methods, both of which suffer from time and yield limitations $[1,3]$. Thus in the present study, we cloned synthetic oligonucleotides that encoded BAP and overexpressed these in E. coli. The recombinant method for obtaining this short peptide (11 amino acids) involved the construction of a synthetic oligonucleotide stretch encoding the putative precursor, which has a cleavage site for the enzyme pepsin to cleave and release only the BAP casoplatelin. The codon frequency table of E. coli was consulted for each amino acid of casoplatelin, and the DNA sequence was designed with two pepsin cleavage sites flanking the synthetic construct.

\subsection{Synthesis and Annealing of Oligonucleotides}

Annealing of oligonucleotides was performed in annealing buffer at $95^{\circ} \mathrm{C}$ for $5 \mathrm{~min}$ to promote the formation of hydrogen bonds between complementary single-stranded DNA molecules. Annealed products were further characterized using gel electrophoresis, and a thick band corresponding to $50 \mathrm{bp}$ was observed, indicating successful annealing (Fig. 2a).

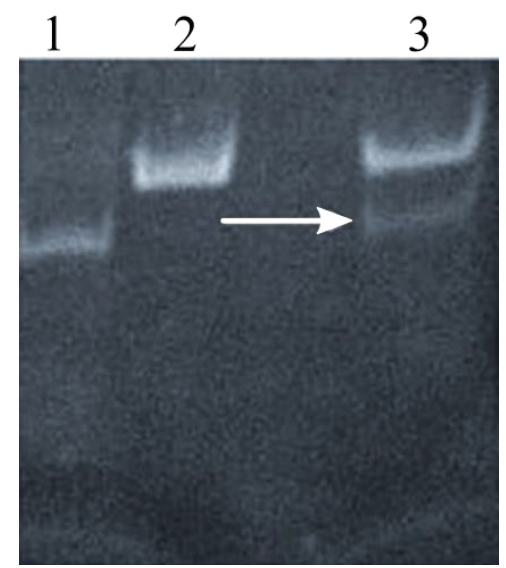

Fig. (2a). Agarose gel electrophoresis images showing the presence of annealed oligonucleotides and their characterization. Synthesized oligonucleotides and the annealed product (Lane 1 - 45 nucleotide length oligonucleotides; Lane 2 - 53 nucleotide length oligonucleotide; Lane 3 - Annealed product (indicated by arrow) showing that the conditions were favorable for annealing the oligonucleotides.

\subsection{Cloning and Characterization of Cloned Oligonuc- leotides}

To achieve directional cloning, Sac I and Hind III precleaved sites were added to both ends of the pBADgIII vector sequence. Because mobility shifts of $50 \mathrm{bp}$ are difficult to measure, a single-stranded probe was added to the construct. BLASTN (https://blast.ncbi.nlm.nih.gov/Blast.cgi) [19] searches of known vector databases and the E.coligenome were performed using the probe sequence to eliminate non-specific binding to any region of the vector. The present pBAD expression system released the expressed product outside the cell with the gIII signal sequence. The pro-peptide was found as a fusion protein with a $6 \times$ histidine tag in the periplasm. The protein digestion tool (https://web.expasy.org /peptide_cutter/) [20] was checked to see which peptide digestion products were released by pepsin digestion. This prediction showed that the predominant products after digestion were casoplatelin and the $6 \times$ histidine tag. The prediction of peptide digestion capability of ExPASy has been showcased in the case of casein-based ACE-inhibitory peptide [21] and angiotensin I-converting enzyme inhibitory peptide [22]. Thus, the use of ExPASy in correctly identifying the peptides from a precursor protein has been successful.

The linearized pBADgIII vector was then cloned with the annealed oligonucleotide and was then used to transform E.coli TOP10 cells. After growth in ampicillin rich LB media plates, resistant colonies were selectively grown to isolate plasmid for characterization in Dot-Blot Southern hybridization assays using the upward capillary transfer method. This method enabled the detection of recombinant clones with a non-isotope labeled probe (Fig. 2b). Usage of Southern hybridization assays for the detection of recombinant clones has been also reported with the recombinant $\mathrm{CHH}-\mathrm{B} 1$ [23] and (CHH-B2) [24]. Clones were then verified using Dot-Blot Southern hybridization and were induced in the presence of $0.1 \%$ arabinose for overexpression of casoplatelin. 


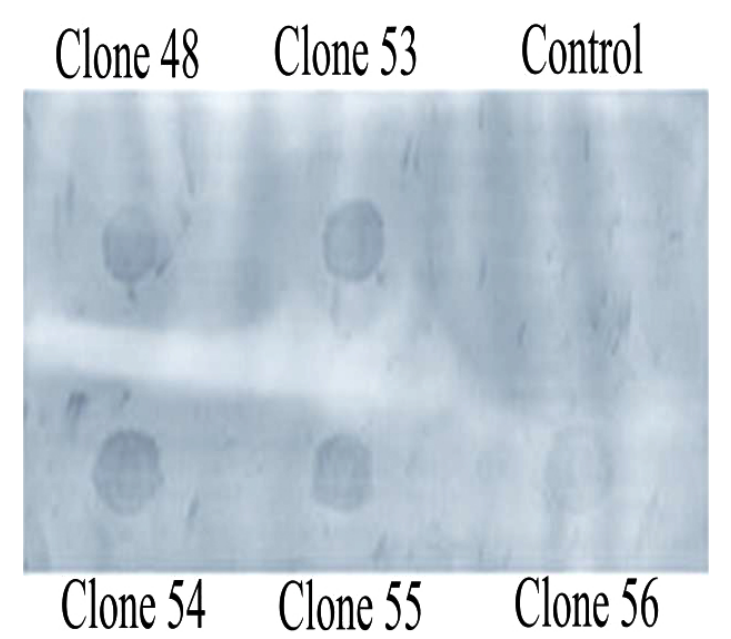

Fig. (2b). Detection of recombinant pBAD clones by Dot-Blot hybridization showing that the recombinant $\mathrm{pBAD}$ cloning vector had the annealed oligonucleotide inserted in them.

\subsection{Overexpression and Purification of Casoplatelin}

Analyses of supernatants in $20 \%$ Tris-Tricine SDSpolyacrylamide gels revealed a band corresponding to a $5-\mathrm{kDa}$ protein, which was absent in control and was the estimated molecular mass of the pro-peptide (data not shown). The expressed product was purified using a Ni-NTA column purification kit from Qiagen, USA. A band corresponding to 5 $\mathrm{kDa}$ was seen in the elute (Fig. 3a) and the purified product was digested using pepsin in a gastric buffer.

\subsection{Platelet Aggregation Assay}

Effects of casoplatelin on ADP-induced aggregation of platelets were tested at a molar ratio with human fibrinogen of $30: 1$. Following the addition of the 30 -fold molar excess of the peptide to the reaction, aggregation was monitored by recording absorbance at $500 \mathrm{~nm}$ every $\min$ for $15 \mathrm{~min}$. The control comprised the reaction mix without inducer (ADP) and absorbance was recorded every $10 \mathrm{~s}$ for $1 \mathrm{~min}$. After the addition of ADP, readings were taken every $5 \mathrm{~min}$ for $1 \mathrm{~h}$ at the same wavelength. Absorbance values were plotted as a function of time (Fig. 3b), which decreased rapidly in control, indicating progressive aggregation of platelets. In contrast, the absorbance of test samples containing peptide increased for the first two min and gradually decreased after that, with little change over ten min. These observations are direct evidence that casoplatelin inhibits ADP-induced platelet aggregation. The progressive aggregation of platelets coupled with antiplatelet activity has also been reported with $\mathrm{Cc}_{3}$-SPase [25] and sheep lactoferrin [26].

\subsection{Prediction of 3D Structure and Computational Model of Casoplatelin and its Interaction with Fibrinogen}

The undecapeptide (residues 106-116) casoplatelin comp- rises regions with hydrophobic residues (106-109) and hydrophilic residues (110-116). The N-terminal undecapeptide of cow $\kappa$-caseinoglycopeptide (residues 106-116 of $\kappa$-casein) reportedly has anti-platelet activity and inhibits platelet aggregation. In addition, two smaller tryptic peptides (residues 106-112 and 113-116) and one longer peptide (residues 103-111 of $\kappa$-casein, around the chymosin) of this undecapeptide have been shown to have moderate effects on platelet aggregation but no anti-platelet activity [27].

Computational analyses of casoplatelin were performed using Robetta [16], which requires a minimum of 27 amino acids. Thus, we added eight $\kappa$-casein precursor amino acids onto both sides of the casoplatelin peptide, and predicted the structure of the resulting 27-residue sequence using $2 \mathrm{kon}$ as the template, which was identified from Robetta's inbuilt Ginzu domain prediction tool. To build a computational model of casoplatelin binding to fibrinogen (Fig. 4), five models were predicted by Robetta with a score of 0.38 , indicating that the predicted structure was of medium-high quality. Although peptides can generally assume any three-dimensional shape, Robetta predicted two models with beta-strand pairing (models 1 and 4), indicating a high probability that casoplatelin is enriched with $\beta$-strands.

To develop a computational model of casopla-telinfibrinogen interactions, we performed molecular docking using AutoDock $4.2[17,28]$. AutoDock has been used previously to predict interactions between peptides and proteins, and molecular docking analyses have been successful in similar studies [29, 30]. Five models were prepared for AutoDock with 32 maximum torsion or rotatable bonds for each molecule. Although the peptide model contained more than 100 rotatable bonds, we reduced this number to 32 by making amide and backbone bonds as non-rotatable. Additionally, polar hydrogens and partial Gasteiger charges were added to complete the ligand processing step $[31,32]$. The molecular docking results of casoplatelin showed interactions with fibrinogen A, B, or C chains in each of the peptide models as shown in Fig. (5).

Specifically, Model 1 interacted with the $\mathrm{C}$ chain, Model 2 interacted with $\mathrm{A}$ and $\mathrm{C}$ chains, Model 3 interacted with the $\mathrm{B}$ chain, and Model 5 interacted with the $\mathrm{C}$ chain. Fibrinogen predominantly comprises coiled-coil regions, and terminates with specific globular domains of domain $\mathrm{D}$, where the Cterminal ends of $\mathrm{B} \beta$ and $\mathrm{B} \gamma$ and $\mathrm{A} \alpha$ are interlinked (Table 2). Specifically, in the Aachain, the $\mathrm{C}$-terminal region extends from domain $\mathrm{D}$, which can interact with another $\mathrm{A} \alpha \mathrm{C}$-terminal region, and also with the $\mathrm{E}$ domain. These types of intermolecular interactions with fibrinogen lead to clot formation via cross-linking. Thus, fibrinogen $\mathrm{E}$ and $\mathrm{D}$ domains contain crucial interaction regions for conversion to fibrin. The molecular interactions of a peptide with fibrinogen towards anti-plate activity are also reported through the molecular docking studies in the case of Mytilusedulis protein hydrolysates [33] and Staphylococcus aureus coagulase [34]. 


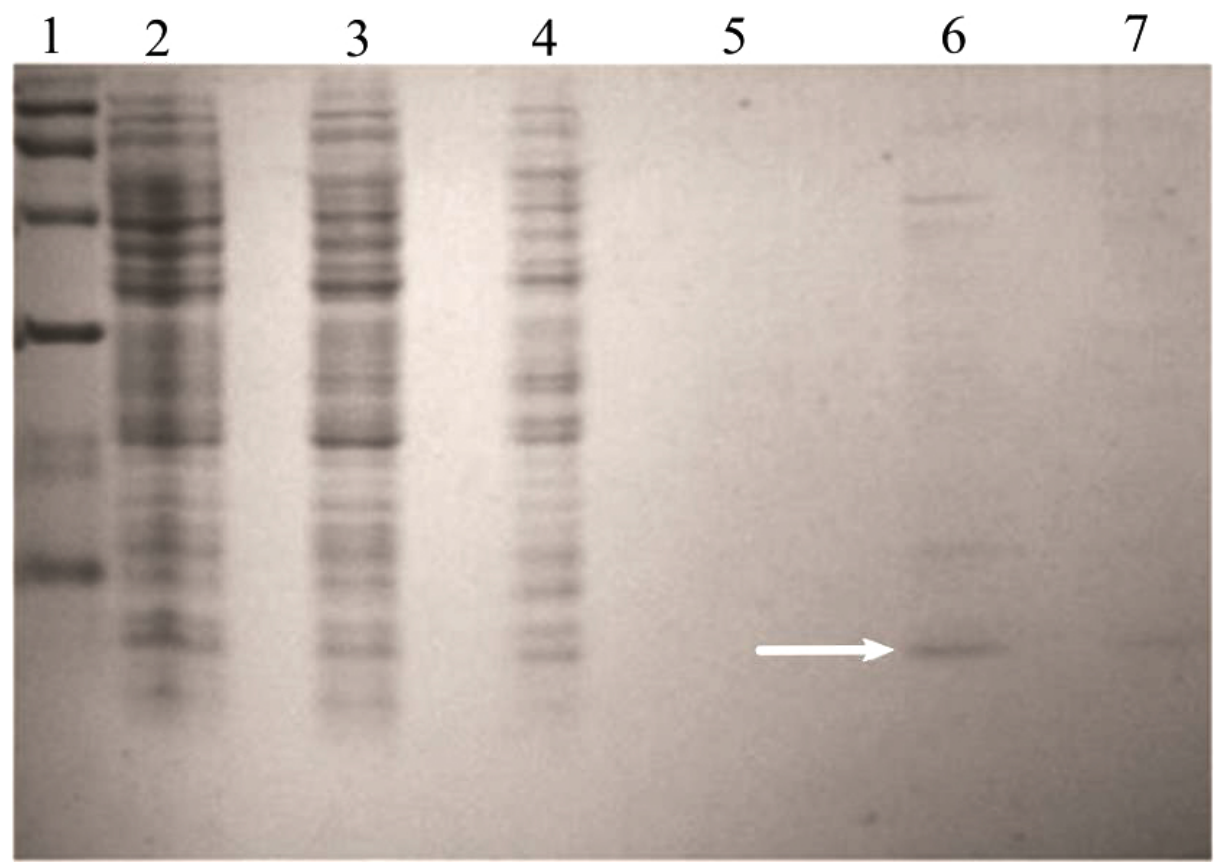

Fig. (3a). SDS-PAGE (20\% Acrylamide and Tris/Tricine Buffer) Ni-NTA column purification of $5 \mathrm{kDa}$ protein from the clone carrying recombinant pBAD C(Lane 1 - Protein Molecular mass marker; Lane 2 - Cell Lysate; Lane 3 - Flow-through; Lane 4 - First wash; Lane 5 - Second wash; Lane 6 First Eluate (concentrated); Lane 7 - Second Eluate (dilute); Arrow indicates the $5 \mathrm{kDa}$ protein). The image shows that the $5 \mathrm{kDa}$ protein was able to be successfully expressed from the recombinant pBAD vector in the transformed $E$. coli cells.

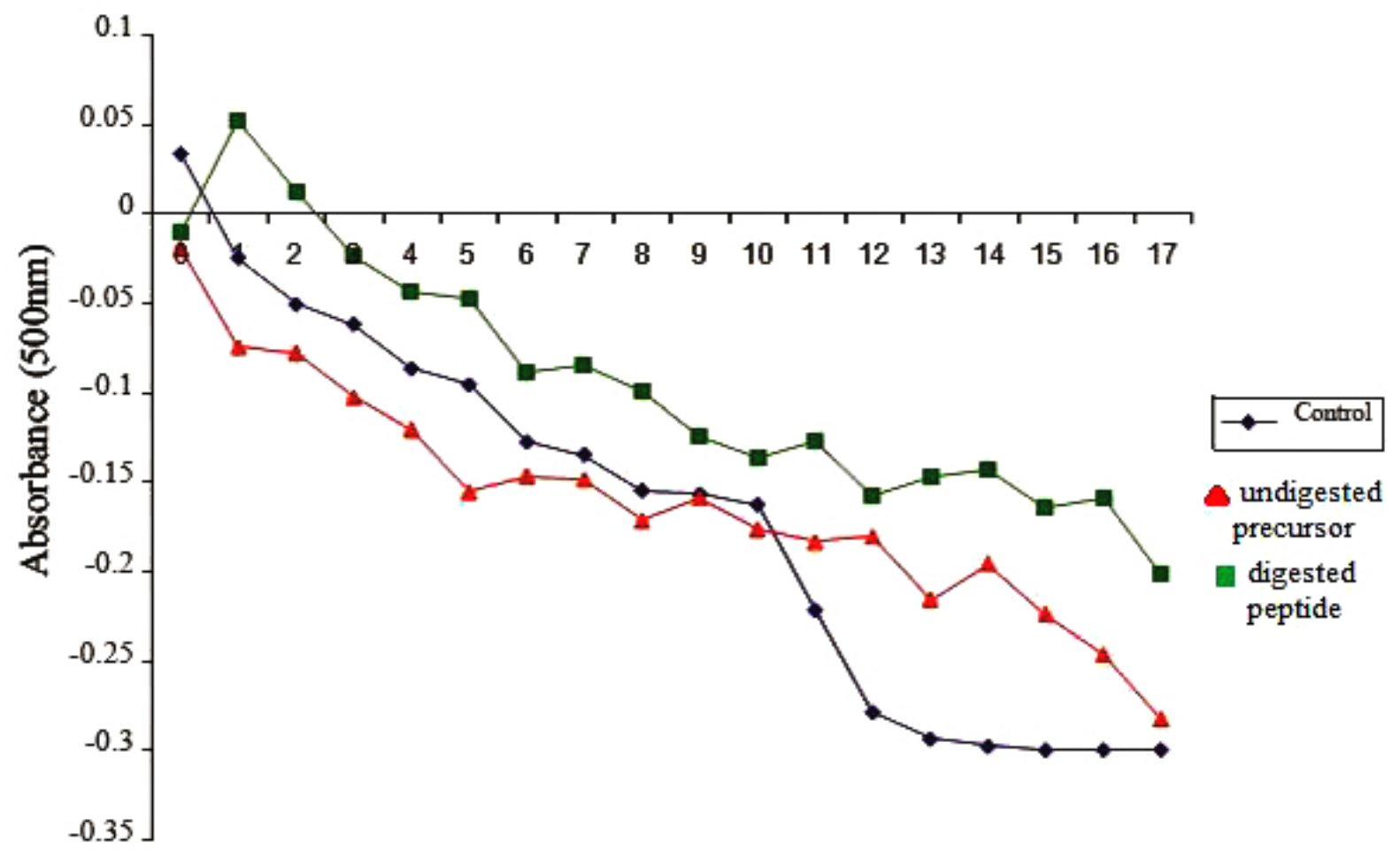

\section{Time (minutes)}

Fig. (3b). Effect of MAIPPKKNQDK and undigested precursor (indicated in red triangles) on ADP-induced aggregation of washed human platelets showing that the peptide (indicated in green squares) had the desired effect of preventing the formation of platelet aggregation in comparison to the undigested precursor. The control is shown in blue diamonds. 


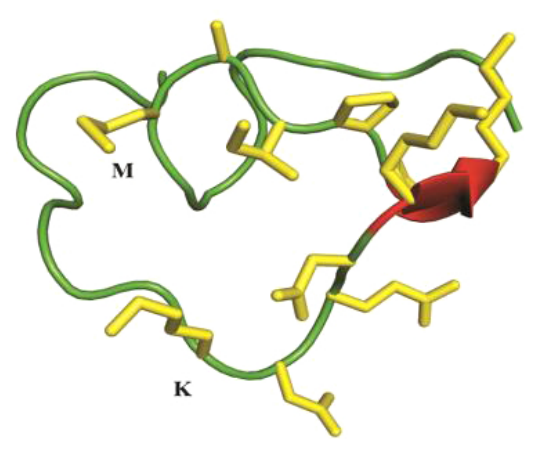

Model 1

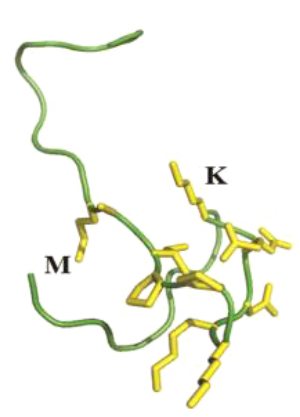

Model 2

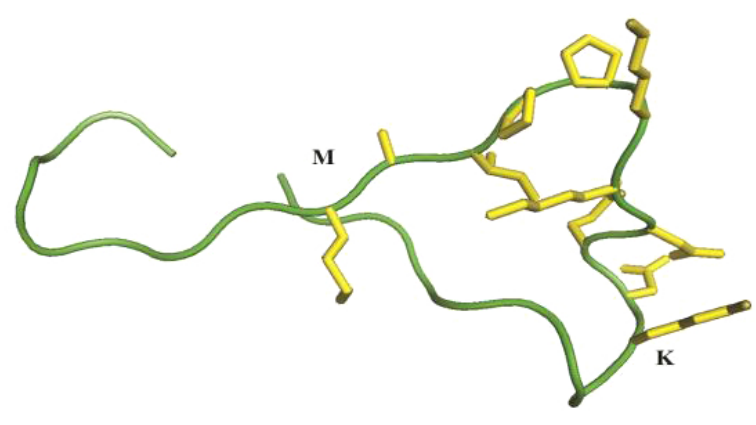

Model 3
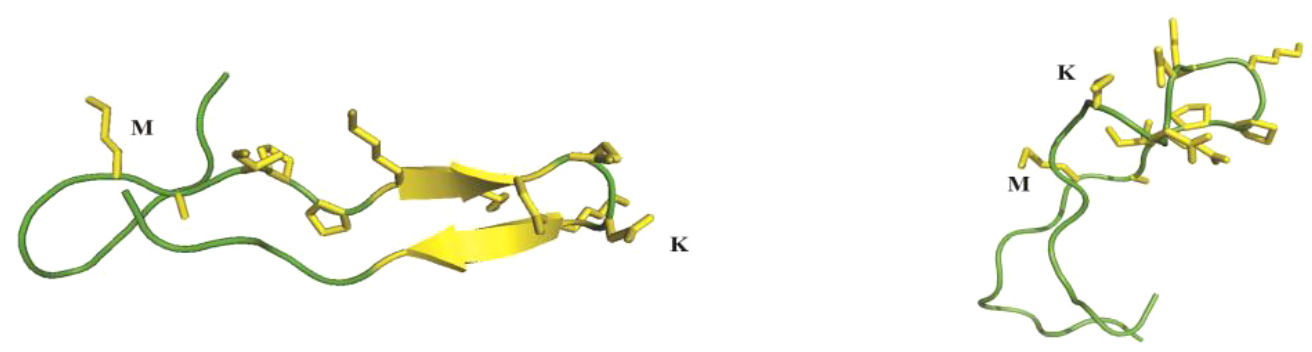

Model 4

Model 5

Fig. (4). De novo 3D structure prediction of casoplatelin from Rosetta. While four models (Models 1, 2, 3, and 5) are predicted without any secondary structure, Model 4 is predicted to contain $\beta$-strands. This computational model proposes the possible confirmations of the peptide in its most stable form.

Table 2. Predicted Interaction between fibrinogen and Casoplatelin from LIGPLOT

\begin{tabular}{|c|c|c|c|c|c|c|}
\hline Model Number & Autodock Run Number & Fibrinogen & Casoplatelin & Hydrogen Bond & \multicolumn{2}{|c|}{$\begin{array}{l}\text { Hydrophobic } \\
\text { Interactions }\end{array}$} \\
\hline \multirow{3}{*}{ Model 1} & \multirow{3}{*}{5} & \multirow{3}{*}{$\mathrm{C}$} & \multirow{3}{*}{$\mathrm{D}$} & \multirow{3}{*}{-} & Phe C 322 & Lys D 15 \\
\hline & & & & & Glu C 323 & Asn D 16 \\
\hline & & & & & Asp C 318 & Ala D 10 \\
\hline Model 2 & 2 & $\mathrm{~A}$ & $\mathrm{D}$ & - & Ala A 142 & Lys D 14 \\
\hline Model 2 & 2 & $\mathrm{~B}$ & $\mathrm{D}$ & Gln D 17 - Arg B 391 & Arg B 391 & Lys D 19 \\
\hline Model 2 & 2 & $\mathrm{C}$ & $\mathrm{D}$ & \begin{tabular}{|l|}
- \\
\end{tabular} & Tyr C 114 & Lys D 14 \\
\hline \multirow{4}{*}{ Model 3} & \multirow{4}{*}{6} & \multirow{4}{*}{ B } & \multirow{4}{*}{$\mathrm{D}$} & \multirow{4}{*}{$\begin{array}{l}\text { His D } 1 \text { - Tyr B } 345 \\
\text { Phe D } 8 \text { - Asp B } 355\end{array}$} & Asn B 351 & Phe D 8 \\
\hline & & & & & Trp B 440 & Lys D 14 \\
\hline & & & & & Ser B 358 & Pro D 23 \\
\hline & & & & & Thr B 348 & Pro D 12 \\
\hline \multirow{5}{*}{ Model 4} & \multirow{5}{*}{3} & \multirow{5}{*}{ A } & \multirow{5}{*}{$\mathrm{D}$} & \multirow{5}{*}{-} & Arg A 167 & His D 5 \\
\hline & & & & & Ala A 170 & His D 3 \\
\hline & & & & & Glu A 172 & Pro D 13 \\
\hline & & & & & Asp A 174 & Lys D 15 \\
\hline & & & & & Asp A 177 & Lys D 19 \\
\hline \multirow{3}{*}{ Model 4} & \multirow{3}{*}{3} & \multirow{3}{*}{ B } & \multirow{3}{*}{$\mathrm{D}$} & \multirow{3}{*}{ Asn D 26 - Tyr B 192} & Lys B 181 & Glu D 21 \\
\hline & & & & & Asp B 185 & Pro D 23 \\
\hline & & & & & Lys B 178 & Lys D 19 \\
\hline Model 5 & 1 & B & $\mathrm{D}$ & Thr D 27 - Arg B 176 & Glu B 183 & Pro D 13 \\
\hline Model 5 & 1 & $\mathrm{C}$ & $\mathrm{D}$ & - & Lys C 127 & Pro D 13 \\
\hline
\end{tabular}



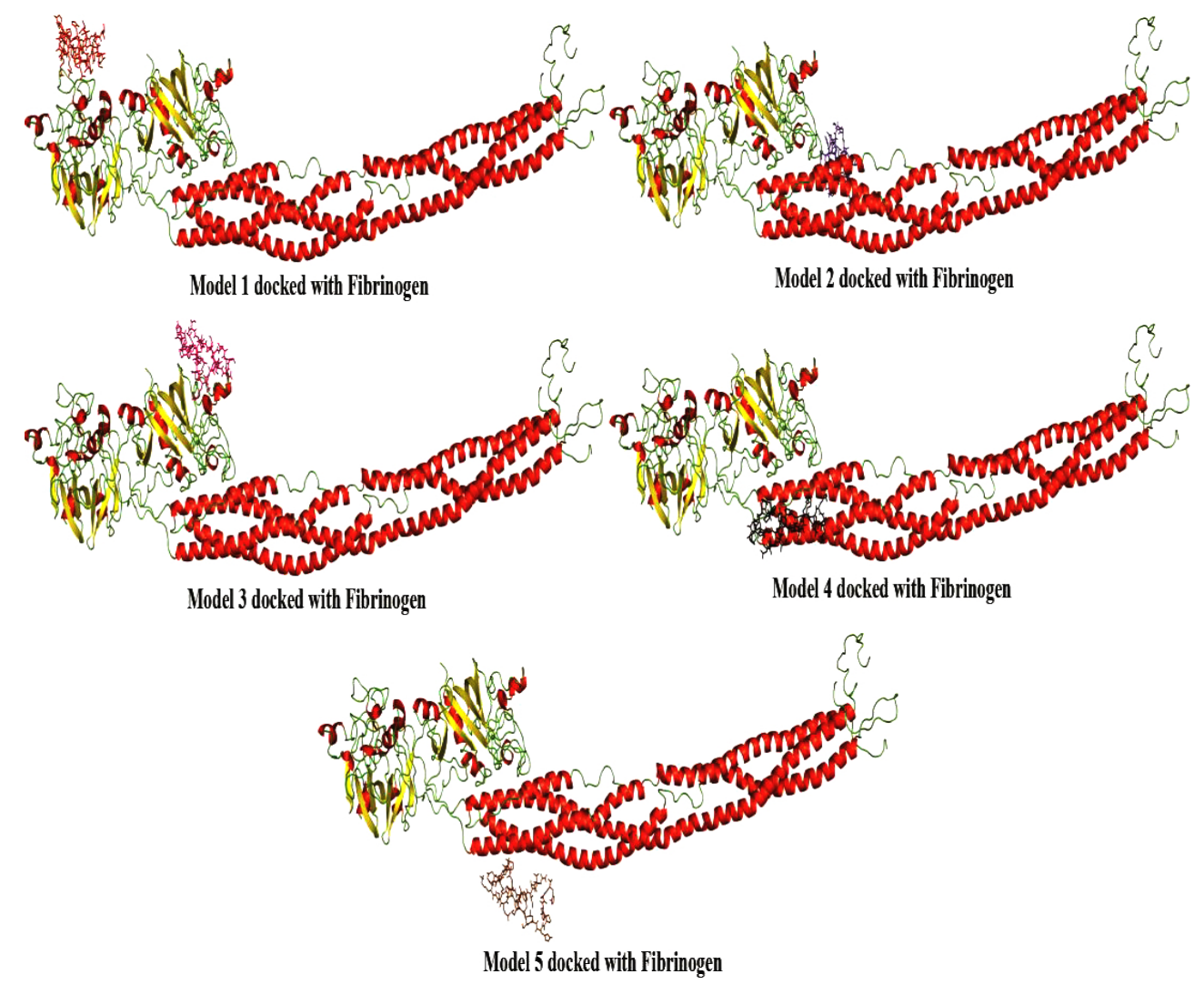

Fig. (5). Proposed models for casoplatelin and fibrinogen interaction. The five models (labeled Model 1 to Model 5) of casoplatelin obtained from Rosetta are shown in their post-docked orientation. The peptides are shown in stick representation, where three models are shown to bind to the helical region of Fibrinogen and two models are shown to bind to the "head" part of the protein. The model explains the mode of interaction with the $\mathrm{C}$ chain of fibrinogen and thus possibly prevents the formation of thrombotic clots.

\section{CONCLUSION}

In this study, we used a novel E.coli recombinant method (first of its kind) to produce the bioactive $\kappa$-casein derived peptide casoplatelin. The recombinant bioactive peptide was then expressed and its anti-thrombotic activities were tested in ADP-induced platelet aggregation assays. These experiments showed that at a casoplatelin:human fibrinogen molar ratio of 30:1, casoplatelin inhibited ADP-induced platelet aggregation. Subsequent in silico modeling of the 3D structure of casoplatelin using Robetta and AutoDock indicated that for fibrinogen interaction, casoplatelin is most likely to favor the $\beta$-strands in the fibrinogen structure.

\section{ABBREVIATIONS}

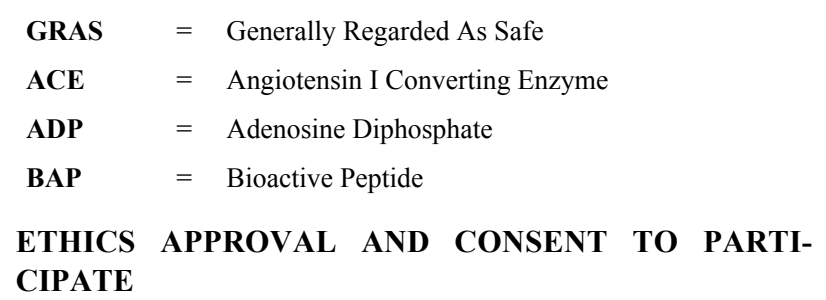

No ethical approval was required for this study.

\section{HUMAN AND ANIMAL RIGHTS}

Not applicable.

\section{CONSENT FOR PUBLICATION}

Not Applicable.

\section{AVAILABILITY OF DATA AND MATERIALS}

The authors confirm that the data supporting the findings of this study are available within the article.

\section{FUNDING}

None.

\section{CONFLICTS OF INTEREST}

The authors declare that they do not have any conflicts of interest.

\section{ACKNOWLEDGEMENTS}

We thank Manjula Saravanan for providing help in performing experiments. We also thank Amita Gorur for assistance in the experiments.

\section{REFERENCES}

[1] Saadi S, Saari N, Anwar F, Abdul Hamid A, Ghazali HM. Recent advances in food biopeptides: Production, biological functionalities and therapeutic applications. Biotechnol Adv 2015; 33(1): 80-116. [http://dx.doi.org/10.1016/j.biotechadv.2014.12.003] [PMID: 25499177]

[2] Raikos V, Dassios T. Health-promoting properties of bioactive peptides derived from milk proteins in infant food: A review. Dairy 
Sci Technol 2014; 94: 91-101

[http://dx.doi.org/10.1007/s13594-013-0152-3] [PMID: 24511365]

[3] Lee AC, Harris J L, Khanna K K, Hong J. A comprehensive review on current advances in peptide drug development and design. Int J Mol Sci 2019; 20: 2383-404

[http://dx.doi.org/10.3390/ijms20102383]

[4] Phelan M, Aherne A, Gerald ACF, O'Brien NM. Casein-derived bioactive peptides: .biological effects, industrial uses, safety aspects and regulatory status. IntDairy J 2019; 19: 643-54.

[http://dx.doi.org/10.1016/j.idairyj.2009.06.001]

[5] Li-Chan ECY. Bioactive peptides and protein hydrolysates: Research trends and challenges for application as nutraceuticals and functional food ingredients. Curr Opin Food Sci 2015; 1: 28-37.

[http://dx.doi.org/10.1016/j.cofs.2014.09.005]

[6] Robitaille G, Champagne CP. Growth-promoting effects of pepsinand trypsin-treated caseinomacropeptide from bovine milk on probiotics. J Dairy Res 2014; 81(3): 319-24.

[http://dx.doi.org/10.1017/S0022029914000247] [PMID: 24960102]

[7] Ren Y, Yang Y, Wu W, Zhang M, Wu H, Li X. Identification and characterization of novel anticoagulant peptide with thrombolytic effect and nutrient oligopeptides with high branched chain amino acid from Whitmania pigra protein. Amino Acids 2016; 48(11): 2657-70. [http://dx.doi.org/10.1007/s00726-016-2299-8] [PMID: 27487778]

[8] Rojas-Ronquillo R, Cruz-Guerrero A, Flores-Nájera A, et al. Antithrombotic and angiotensin-converting enzyme inhibitory properties of peptides released from bovine casein by Lactobacillus caseiShirota. Int Dairy J 2012; 26: 147-54 [http://dx.doi.org/10.1016/j.idairyj.2012.05.002]

[9] Hartmann R, Meisel H. Food-derived peptides with biological activity: From research to food applications. Curr Opin Biotechnol 2007; 18(2): 163-9.

[http://dx.doi.org/10.1016/j.copbio.2007.01.013] [PMID: 17292602]

[10] Korhonen H, Pihlanto A. Bioactive peptides: Production and functionality. Int Dairy J 2006; 16: 945-60.

[http://dx.doi.org/10.1016/j.idairyj.2005.10.012]

[11] Chauhan M, Yennamalli RM, Garlapati VK. biochemical and molecular characterization of a unique lipase from Staphylococcus arlettae JPBW-1. Eng Life Sci 2016; 16: 762-8.

[http://dx.doi.org/10.1002/elsc.201600074] [PMID: 23955348]

[12] Iwaniak A, Minkiewicz P, Darewicz M, Protasiewicz M, Mogut D. Chemometrics and cheminformatics in the analysis of biologically active peptides from food sources. J Funct Foods 2015; 16: 334-51. [http://dx.doi.org/10.1016/j.jff.2015.04.038]

[13] Meng XY, Zhang HX, Mezei M, Cui M. Molecular docking: A powerful approach for structure-based drug discovery. Curr Comput Aided Drug Des 2011; 7(2): 146-57.

[http://dx.doi.org/10.2174/157340911795677602] [PMID: 21534921]

[14] Cecchini F, Iacumin L, Fontanot M, Comi G, Manzano M. Identification of the unculturable bacteria Candidatus arthromitus in the intestinal content of trouts using Dot blot and Southern blot techniques. Vet Microbiol 2012; 156(3-4): 389-94. [http://dx.doi.org/10.1016/j.vetmic.2011.11.020] [PMID: 22186616]

[15] Schägger H. Tricine-SDS-PAGE. Nat Protoc 2006; 1(1): 16-22. [http://dx.doi.org/10.1038/nprot.2006.4] [PMID: 17406207]

[16] Kim DE, Chivian D, Baker D. Protein structure prediction and analysis using the Robetta server. Nucleic Acids Res 2004; 32(Web Server issue)W526-31

[http://dx.doi.org/10.1093/nar/gkh468] [PMID: 15215442]

[17] Morris GM, Huey R, Lindstrom W, et al. AutoDock4 and AutoDockTools4: Automated docking with selective receptor flexibility. J Comput Chem 2009; 30(16): 2785-91. [http://dx.doi.org/10.1002/jcc.21256] [PMID: 19399780]

[18] Laskowski RA, Swindells MB. LigPlot+: Multiple ligand-protein interaction diagrams for drug discovery. J Chem Inf Model 2011; 51(10): 2778-86

[http://dx.doi.org/10.1021/ci200227u] [PMID: 21919503]

[19] Altschul SF, Gish W, Miller W, Myers EW, Lipman DJ. Basic local alignment search tool. J Mol Biol 1990; 215(3): 403-10.
[http://dx.doi.org/10.1016/S0022-2836(05)80360-2] [PMID: 2231712] 20] Gasteiger E, Hoogland C, Gattiker A, et al. 2005.

[21] Tu M, Wang C, Chen C, et al. Identification of a novel ACE-inhibitory peptide from casein and evaluation of the inhibitory mechanisms. Food Chem 2018; 256: 98-104.

[http://dx.doi.org/10.1016/j.foodchem.2018.02.107]

[PMID: 29606478]

[22] Lin K, Zhang LW, Han X, et al. Yak milk casein as potential precurso of angiotensin I-converting enzyme inhibitory peptides based on in silico proteolysis. Food Chem 2018; 254: 340-7.

[http://dx.doi.org/10.1016/j.foodchem.2018.02.051]

[PMID: 29548462]

[23] Camacho-Jiménez L, Sánchez-Castrejón E, Ponce-Rivas E, et al. 2015.

[24] Camacho-Jiménez L, Sánchez-Castrejón E, Díaz F, Aguilar MB, Muñoz-Márquez ME, Ponce-Rivas E. Cloning and expression of the recombinant crustacean hyperglycemic hormone isoform $\mathrm{B} 2 \mathrm{(rCHH}-$ B2) and its effects on the metabolism and osmoregulation of the Pacific white shrimp Litopenaeus vannamei. Gen Comp Endocrinol 2017; 253: 33-43

[http://dx.doi.org/10.1016/j.ygcen.2017.08.020] [PMID: 28842215]

[25] Chérifi F, Saoud S, Laraba-Djebari F. Molecular modeling, biochemical characterization, and pharmacological properties of $\mathrm{Cc}_{3}$ SPase: A platelet-aggregating thrombin-like enzyme purified from Cerastes cerastes venom. J Biochem Mol Toxicol 2018; 32e22165 [http://dx.doi.org/10.1002/jbt.22165] [PMID: 29979475]

[26] Qian ZY, Jollès P, Migliore-Samour D, Fiat AM. Isolation and characterization of sheep lactoferrin, an inhibitor of platelet aggregation and comparison with human lactoferrin. Biochim Biophys Acta $1995 ; 1243(1): 25-32$

[http://dx.doi.org/10.1016/0304-4165(94)00126-I] [PMID: 7827104]

[27] Rizzello CG, Losito I, Gobbetti M, Carbonara T, De Bari MD Zambonin PG. Antibacterial activities of peptides from the watersoluble extracts of Italian cheese varieties. J Dairy Sci 2005; 88(7): 2348-60.

[http://dx.doi.org/10.3168/jds.S0022-0302(05)72913-1] [PMID: 15956298]

[28] Rentzsch R, Renard BY. Docking small peptides remains a great challenge: an assessment using AutoDock Vina. Brief Bioinform 2015; 16(6): 1045-56.

[http://dx.doi.org/10.1093/bib/bbv008] [PMID: 25900849]

[29] Le CF, Yusof MY, Hassan MA, Lee VS, Isa DM, Sekaran SD. In vivo efficacy and molecular docking of designed peptide that exhibits potent antipneumococcal activity and synergises in combination with penicillin. Sci Rep 2015; 5: 11886

[http://dx.doi.org/10.1038/srep11886] [PMID: 26156658]

[30] Serçinoğlu O, Özcan G, Kabaş ZK, Ozbek P. A computational docking study on the $\mathrm{pH}$ dependence of peptide binding to HLA-B27 sub-types differentially associated with ankylosing spondylitis. J Comput Aided Mol Des 2016; 30(7): 569-81

[http://dx.doi.org/10.1007/s10822-016-9934-z] [PMID: 27506766]

[31] King MD, Phillips P, Turner MW, et al. Computational exploration of a protein receptor binding space with student proposed peptide ligands. Biochem Mol Biol Educ 2016; 44(1): 63-7.

[http://dx.doi.org/10.1002/bmb.20925] [PMID: 26537635]

[32] Huang J, Hua W, Li J, Hua Z. Molecular docking to explore the possible binding mode of potential inhibitors of thioredoxin glutathione reductase. Mol Med Rep 2015; 12(4): 5787-95. [http://dx.doi.org/10.3892/mmr.2015.4119] [PMID: 26239395]

[33] Qiao M, Tu M, Chen H, Mao F, Yu C, Du M. Identification and in silico prediction of anticoagulant peptides from the enzymatic hydrolysates of Mytilus edulis proteins. Int J Mol Sci 2018; 19(7): 2100 .

[http://dx.doi.org/10.3390/ijms19072100] [PMID: 30029529]

[34] Thomas S, Liu W, Arora S, Ganesh V, Ko YP, Höök M. The complex fibrinogen interactions of the Staphylococcus aureus coagulases. Front Cell Infect Microbiol 2019; 9: 106.

[http://dx.doi.org/10.3389/fcimb.2019.00106] [PMID: 31041195]

This is an open access article distributed under the terms of the Creative Commons Attribution 4.0 International Public License (CC-BY 4.0), a copy of which is available at: (https://creativecommons.org/licenses/by/4.0/legalcode). This license permits unrestricted use, distribution, and reproduction in any medium, provided the original author and source are credited. 